\title{
Palm kernel expeller increases milk fat content when fed to grazing dairy cows
}

\author{
J.D.V. van Wyngaard ${ }^{\#}$ \& R. Meeske \\ Western Cape Department of Agriculture, Outeniqua Research Farm, P.O. Box 249, George, 6530, South Africa
}

(Received 6 December 2016; Accepted 3 March 2017; First published online 13 March 2017)

Copyright resides with the authors in terms of the Creative Commons Attribution 4.0 South African Licence.

See: http://creativecommons.org/licenses/by/4.0/za

Condition of use: The user may copy, distribute, transmit and adapt the work, but must recognise the authors and the South African Journal of Animal Science.

\begin{abstract}
Palm kernel expeller (PKE) is a feed by-product that is used by the dairy and beef industries. This study investigated the effect of partially replacing maize with PKE in a dairy concentrate on milk and ruminal fermentation parameters of Jersey cows grazing kikuyu-ryegrass pasture. Seventy-two multiparous cows were blocked according to milk yield, days in milk, and lactation number and randomly allocated within blocks to one of four treatment concentrates: PKE0, PKE10, PKE20, and PKE30, containing 0, 100, 200, and $300 \mathrm{~g} \mathrm{PKE} / \mathrm{kg}$ dry matter (DM), respectively. Eight rumen-cannulated lactating cows were used in a $4 \times 4$ Latin square design. All cows grazed pasture as one group, and concentrate was fed at $5.4 \mathrm{~kg} \mathrm{DM} / \mathrm{cow}$ per day. Pasture was allocated at $11.1 \mathrm{~kg} \mathrm{DM} / \mathrm{cow}$ per day. Milk yield was lower with PKE30 than PKE0 (14.3 versus $15.6 \mathrm{~kg} / \mathrm{cow}$ per day, respectively). Feeding PKE20 and PKE30 was associated with a higher milk fat content of 50.6 and $52.9 \mathrm{~g} / \mathrm{kg}$, respectively, than that of 46.3 and $49.3 \mathrm{~g} / \mathrm{kg}$ of cows fed PKE0 and PKE10, respectively. However, feeding PKE30 compromised fibre degradability. Increased milk fat content and sustained milk yield indicated that $200 \mathrm{~g} \mathrm{PKE} / \mathrm{kg}$ DM can partially replace maize in a dairy concentrate, resulting in a possible added economical advantage, which is dependent on the milk payment system. The lack of a significant effect on milk fat yield and the negative linear relationship of milk protein to milk fat ratio, induced by PKE inclusion, may be unfavourable for certain milk payment systems.
\end{abstract}

Keywords: By-product, fibre-based concentrate, Jersey cow, pasture, ruminal fermentation

\# Corresponding author: josefvw@elsenburg.com

\section{Introduction}

Since 2014, international dairy product prices have shown an exceedingly volatile and downward trend (Coetzee, 2016a). This has resulted in lower raw milk producer prices, which have jeopardised the South African long-term raw milk producer price to feed price ratio of 1.3 to 1 (Coetzee, 2016b). As a result, dairy farmers have lost their competitive advantage. To counter this economic slump, dairy farmers should consider alternative feed sources that are less expensive and high in digestible fibre to reduce the high feed cost and increase milk solids, respectively. An increase in milk solids, such as milk fat and milk protein, could lead to an increase in the raw milk producer price; hence dairy farmers would regain their competitive edge.

Palm kernel expeller is a low-cost high-fibre by-product of the palm oil industry, and has been used extensively as a feed by the dairy (56\%) and beef (36\%) industries (mainly European Union (EU) countries, southern Asia and Australasia) and to a lesser extent for electricity generation (8\%), worldwide (VirahSawmy, 2014). In New Zealand, PKE is fed predominantly to dairy cattle to supplement pasture feeding in order to act as a short-term pasture extender (Dias, 2010). Since 2014, South Africa has imported about 10 000 Mt PKE annually (Indexmundi, 2017). Palm kernel expeller represents about 50\% of the kernel of the oil palm fruit Elaeis guineensis after oil has been removed via mechanical screw extraction (Abdullah \& Hutagalung, 1988). Palm kernel expeller is one of two types of commercially available palm kernel cake byproducts, the second being solvent-extracted palm kernel cake (SEPKC), which differs in fat content (5-12\% versus $0.5-3.0 \%$, respectively) (Chin, 2001). A detailed description of the palm fruit physiology and oil extraction processes is given by O Mara et al. (1999). Palm kernel expeller, rather than SEPKC, is used as a source of energy, protein, and fibre for dairy cattle at inclusion levels of 300-500 g/kg of total diet (Wan Zahari \& Alimon, 2004). However, an inclusion level of $400 \mathrm{~g} / \mathrm{kg}$ DM has been associated with reduced concentrate intake due to palatability problems (Van Wyngaard et al., 2015). Increasing levels of SEPKC $(50,100$, and $150 \mathrm{~g} / \mathrm{kg} \mathrm{DM})$ in a total mixed ration have been reported not to affect cow DM intake, milk yield 
or milk composition (Carvalho et al., 2006). Correspondingly, milk yield and milk composition (except for milk lactose) were unaffected in a study in which cows grazed high-quality pasture in spring, supplemented with two levels of PKE (200 and $400 \mathrm{~g} / \mathrm{kg} \mathrm{DM}$ ) in a dairy concentrate (Van Wyngaard et al., 2015). In both studies it can be posited that the nutrient supply was at optimum levels. It is plausible that PKE supplementation may induce a positive milk yield and milk composition response when the nutrient supply of a pasture-based system is at sub-optimum level. Pasture quality, such as fibre content and fibre degradability, is influenced by season. It has been reported that the neutral detergent fibre (NDF) content of kikuyu-ryegrass pasture is 130-270 g/kg DM higher in summer than that of the same pasture in spring (Van der Colf et al., 2015), hence, a lower-quality pasture in summer. The combination of increased NDF levels and decreased fibre degradability of summer pasture as opposed to spring pasture and the high NDF content of PKE may induce a positive milk fat content response. This is supported by Zebeli et al. (2008), who stated that NDF intake (physical effective form) enhances milk fat content.

The objective of this study was to compare the effects on milk production, milk composition, and ruminal fermentation end-products from partially replacing maize with increasing levels of PKE in concentrates fed to Jersey cows grazing kikuyu-based pasture during summer. The authors reasoned that if the pasture quality is low in terms of NDF content and degradability, in summer dairy cows will have a positive milk fat response, and will maintain milk yield when supplemented with concentrate containing PKE.

\section{Materials and Methods}

The study was conducted at the Western Cape Department of Agriculture (WCDA), Outeniqua

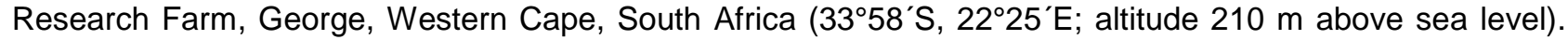
The present study was approved by the Animal Ethics Committee of the WCDA (Approval number AP/NP/D/RM44). The area is characterized by a coastal temperate climate with long-term mean annual precipitation of $732 \mathrm{~mm}$, spread throughout the year (ARC-ISCW, 2011).

The experimental paddock consisted of 8.55 ha of permanent sprinkler-irrigated kikuyu (Pennisetum clandestinum) and annual ryegrass (Lolium multiflorum var. italicum) pasture divided into strips. Preexperimental botanical composition of the pasture (at point of grazing; $n=6$ ) comprised $68.6 \pm 10.6 \%$ kikuyu, $8.6 \pm 5.7 \%$ grass (annual ryegrass and Paspalum dilatatum), $4.8 \pm 3.3 \%$ white clover (Trifolium repens), and $18 \pm 4.8 \%$ broad-leaf weeds. Irrigation was scheduled by irrometer tensiometers (Calafrica SA, Nelspruit, South Africa) installed at a depth of $150 \mathrm{~mm}$. Irrigation was initiated at a tensiometer reading of $-25 \mathrm{kPa}$ and ended at a reading of $-10 \mathrm{kPa}$. Pasture strips were top-dressed with limestone ammonium nitrate (containing $280 \mathrm{~g}$ nitrogen $(\mathrm{N}) / \mathrm{kg}$ ) after each grazing at a rate of $42 \mathrm{~kg} \mathrm{~N} / \mathrm{ha}$. Pasture yield pre- and post-grazing was estimated with a rising plate meter calibrated for this study according to Van der Colf et al. (2015). This linear regression model was used to estimate pasture yield:

$\mathrm{Y}=87.63 \times \mathrm{H}-195.11\left(\mathrm{R}^{2}=0.86\right)$,

Where: $\quad \mathrm{Y}=$ pasture yield, and

$\mathrm{H}=$ rising plate meter height

Seventy-two multiparous Jersey cows, each producing $20.1 \pm 1.93 \mathrm{~kg}$ milk per day (mean $\pm \mathrm{SD}$ ) with $111 \pm 41$ days in milk and $3.4 \pm 1.34$ lactations, were blocked according to pre-experimental milk yield, days in milk, and lactations, and randomly allocated in blocks to four groups. Eight lactating rumen-fistulated Jersey cows (previously fitted with Bar Diamond \#1C rumen cannulae; Bar Diamond Inc, P.O. Box 60, Parma, Idaho, USA) were randomly allocated to the same four groups. Each group was then randomly assigned to one of four treatment concentrates: i) A control (PKE0) concentrate containing $0 \mathrm{~g} \mathrm{PKE} / \mathrm{kg} \mathrm{DM}$; ii) a PKE10 concentrate containing $100 \mathrm{~g}$ PKE/kg DM; iii) a PKE20 concentrate containing $200 \mathrm{~g} \mathrm{PKE} / \mathrm{kg}$ DM; and iv) a PKE30 concentrate containing $300 \mathrm{~g}$ PKE $/ \mathrm{kg}$ DM. The inclusion of PKE partially replaced maize grain and soybean oilcake stepwise. Concentrate was fed at a rate of $5.4 \mathrm{~kg} \mathrm{DM} / \mathrm{cow}$ per day in pellet form. The ingredient composition of each treatment concentrate is presented in Table 1 . Cows were subject to a 14-day dietary adaption period, followed by a 62-day data collection period. The rumen-fistulated cows formed part of a $4 \times 4$ Latin square design with 19-day periods (14 days adaptation and five days data collection).

Cows were kept on pasture and brought in to be milked twice daily, at $0530 \mathrm{~h}$ and $1400 \mathrm{~h}$, using a 20point DairyMaster swingover milking machine with weigh-all electronic milk meters (Tralee Rd, Lissycurrig, Tralee, Co. Kerry, Ireland). Allocated treatment concentrates were offered individually to cows in two equal portions in the dairy parlour during milking. Cows were offered fresh pasture twice daily after milking based on rising plate meter readings to ensure a target post-grazing height of 10 (50 $\mathrm{mm}$ from ground level) (Fulkerson et al., 1999). Access to fresh water was always available. Samples, representative of the concentrate, were collected weekly and pooled bi-weekly. Each week six representative pasture samples were cut $30 \mathrm{~mm}$ from ground level prior to grazing and pooled. Initial DM was determined by drying feed 
samples in a force-draft oven at $60{ }^{\circ} \mathrm{C}$ for 72 hours. Samples of the treatment concentrates and pasture were ground to pass through a 1-mm screen (SMC hammer mill) and stored at $-18^{\circ} \mathrm{C}$ pending analyses.

Milk yield for each cow was measured daily and milk composition (pooled morning and afternoon) was sampled fortnightly. Milk fat, protein, lactose, and milk urea nitrogen (MUN) content were determined by midinfrared spectroscopy and somatic cell count (SCC) by flow cytometry using a FOSS CombiFoss FT+ milk analyser (FOSS, DK-3400, Hillerød, Denmark). Milk yield and milk composition of the rumen-fistulated cows were excluded from the treatment group mean. Bodyweight (Tru-Test EziWeigh v. $1.0 \mathrm{scale}, 0.5 \mathrm{~kg}$ accuracy, Auckland, New Zealand) and body condition score (BCS) were determined over two consecutive days at the start and the end of the data collection period. Body condition was scored using a one-to-five scale scoring system (Wildman et al., 1982).

Table 1 Ingredients of treatment concentrates fed to pasture-based lactating Jersey cows

\begin{tabular}{lcccc}
\hline & \multicolumn{3}{c}{ Treatment concentrate } \\
\cline { 2 - 4 } Ingredient (g/kg DM) & PKE0 $^{1}$ & PKE10 & PKE20 & PKE30 \\
\hline Ground maize & 806 & 732 & 657 & 583 \\
Palm kernel expeller & 0 & 100 & 200 & 300 \\
Soybean oilcake & 115 & 90 & 66 & 41 \\
Molasses & 50 & 50 & 50 & 50 \\
Feedlime & 15 & 14 & 14 & 13 \\
Salt & 6 & 6 & 6 & 6 \\
Magnesium oxide & 3 & 3 & 2 & 2 \\
Vit \& Min Premix & 5 & 5 & 5 & 5
\end{tabular}

Molasweet (powdered feed flavour; Nutec Explicit Nutrition, Block G, Hilton Quarry Office Park, 400 Old Howick Road, Hilton, $\mathrm{KZN}$ ) added at $0.16 \mathrm{~g} / \mathrm{kg}$ DM in each treatment concentrate

${ }_{1}$ PKE: palm kernel expeller; PKE0: concentrate containing 0 g PKE/kg DM; PKE10: concentrate containing $100 \mathrm{~g}$ PKE/kg DM; PKE20: concentrate containing 200 g PKE/kg DM; PKE30: concentrate containing $200 \mathrm{~g} \mathrm{PKE/kg} \mathrm{DM}$

${ }^{2}$ Premix (Cape Feed and Grain Dairy Premix, George, South Africa): 6 million IU vitamin A; 1 million IU vitamin D3; 8000 IU vitamin E; $100 \mathrm{~g} \mathrm{Zn,} 50 \mathrm{~g} \mathrm{Mn}, 20 \mathrm{~g} \mathrm{Cu}, 1.7 \mathrm{~g} \mathrm{l} ; 1 \mathrm{~g} \mathrm{Co} ; 300 \mathrm{mg} \mathrm{Se}$

Pasture, concentrate, and PKE were analysed for DM, ash, crude protein (CP), N (determined with LECO TrumacTM N Determinator, LECO Corporation, Saint Joseph, MI, USA) (CP $=N \times 6.25)$ and crude fat, according to procedures of the Association of Official Analytical Chemists (AOAC) (2000): methods 934.01, 942.05, 968.06 and 920.39, respectively. NDF was determined by the filter bag technique with added heat-stable alpha-amylase (protein enzyme EC 3.2.1.1) (1,4- $\alpha$-D-glucan glucanohydrolase) and anhydrous sodium sulphite and expressed inclusive of residual ash (Robertson \& Van Soest, 1981) using the ANKOM $^{2000}$ fibre analyser, method 9. ADF expressed inclusive of residual ash (Goering \& Van Soest, 1970) (using the ANKOM $^{2000}$ fibre analyser, method 8), ADL (Goering \& Van Soest, 1970) (by solubilization of cellulose with sulphuric acid), and gross energy (GE) (MC-1000 modular calorimeter, operators manual) were also analysed. In vitro organic matter digestibility (IVOMD) was determined according to Tilley \& Terry (1963), using rumen fluid from a rumen-fistulated SA Mutton Merino ram fed good-quality lucerne hay. NDF and ADF residues were analysed for $N$ content to determine neutral detergent insoluble $N$ (NDIN) and acid detergent insoluble $N(A D I N)$, respectively. Mineral composition was determined according to the procedure of AgriLASA (1998), method 6.1.1.

Ruminal $\mathrm{pH}$, fermentation end-products of the rumen, and in situ pasture DM degradability, NDF degradability, and rate of NDF degradability were determined using the rumen-fistulated cows during each 19-day period. Ruminal $\mathrm{pH}$ was measured over a 72-hour period (10 min frequency) with indwelling $\mathrm{pH}-\mathrm{HR}$ $\mathrm{pH} /$ temperature logging systems (TruTrack Data Logger, www.intech.co.nz) attached to the rumen cannula.

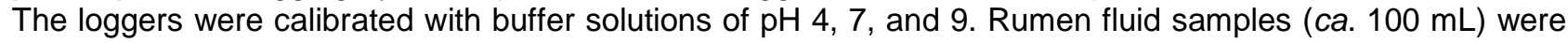
collected from each cow (at 0600, 1400, and 2200 hours and pooled prior analysis) using a vacuum pump and a sampling tube placed into the ventral sac of the rumen via the cannula. The $\mathrm{pH}$ of the ruminal fluid was immediately measured with a handheld pH logger (WTW pH340i pH meter/data logger attached with a WTW Sentix $41 \mathrm{pH}$ electrode). Samples were filtered through four layers of cheesecloth, which separated rumen solids from the ruminal fluid. Filtered samples were subsampled and stored at $-18^{\circ} \mathrm{C}$ for subsequent VFA 
and $\mathrm{NH}_{3}-\mathrm{N}$ analyses according to Broderick \& Kang (1980) modified by Webb (1994). Pasture samples required for the in situ degradability study were cut from the experimental paddock at a height of $30 \mathrm{~mm}$ from ground level prior to grazing and subsequently dried in a force-draft oven at $60{ }^{\circ} \mathrm{C}$ for $72 \mathrm{~h}$. Dried pasture samples were cut into 5-10 mm segments. Five grams of the sample were weighed into nylon bags $(10 \mathrm{~cm} \mathrm{x}$ $20 \mathrm{~cm}$ inner size; $53 \mu \mathrm{m}$ pore size) (Bar Diamond Inc, PO Box 60, Parma, Idaho, USA), attaining a sample size to bag surface area ratio of $12.5 \mathrm{mg} / \mathrm{cm}^{2}$. Replicate nylon bags were incubated in the rumen as described by Cruywagen (2006) for 0, 6, 18, and 30 hours. After incubation, nylon bags were treated similarly to those of Van Wyngaard et al. (2015). Residues were analysed for DM and NDF content parallel to the pasture and concentrate sample analyses and rate of NDF degradability was calculated according to Van Amburgh et al. (2003).

The production measurements of the study were analysed as a randomized complete block design (18 blocks) with ANOVA to test for linear and quadratic contrasts. The treatments were four levels of PKE inclusion in a dairy concentrate, $0,100,200$ and $300 \mathrm{~g} / \mathrm{kg} \mathrm{DM}$. The residuals were acceptably normal with homogeneous treatment variances, except for SCC, which were then log (base 10) transformed. Covariance analysis (milk production, weight and fat corrected milk) was used to test for significant (linear) relationships between the before and after measurements and subsequent for differences between treatment effects. If the relationship was not significant, then ANOVA was used to test for differences between treatment effects on the after measurements. The $\mathrm{pH}$ measurements over 24 hours, time spent below ruminal $\mathrm{pH}$, in situ degradability and rumen fluid parameters were analysed as a replicated $4 \times 4$ Latin square testing for linear and quadratic differences between treatment effects. Time spent below ruminal $\mathrm{pH}$ of 6.2, 6.0, and 5.8 was Poisson distributed and thus analysed with generalized linear model analysis to test for differences between treatment effects. Note that $\mathrm{pH}$ below 5.8 was all zero except for one unit and was thus not statistically analysable. Treatment means were compared using Tukey's least significant difference test at the $5 \%$ level of significance (Snedecor \& Cochran, 1980). Data were analysed using the statistical program GenStat ${ }^{\circledR}$ (Payne, 2014).

\section{Results}

Cows were offered $11 \mathrm{~kg}$ pasture DM/cow per day above $30 \mathrm{~mm}$ ground level, given a pasture yield of $2.2 \mathrm{t} \mathrm{DM} / \mathrm{ha}$. Of the pasture offered, cows consumed only about $69 \%$ daily (Table 2 ). Concentrates were balanced to be iso-protein (Table 3). Increasing levels of PKE increased NDF, ADF, ADL, NDIN, crude fat, $\mathrm{GE}$ and $\mathrm{Ca}: \mathrm{P}$ ratio of the concentrates, concurrently decreasing IVOMD, metabolisable energy (ME), nonfibre carbohydrate (NFC) and ADIN of the concentrates (Table 3). Treatments yielded zero concentrate refusals; however, time spent consuming the PKE30 concentrate was extended. Intakes of the PKE were 0.54, 1.08, and $1.62 \mathrm{~kg} \mathrm{DM} / \mathrm{cow}$ per day for cows fed the PKE10, PKE20, and PKE30 concentrate, respectively.

Table 2 Pre- and post-grazing parameters of experimental kikuyu-dominated pasture

\begin{tabular}{lc}
\hline Parameter & Pasture estimates $(\mathrm{n}=65)$ \\
\hline Pre-grazing & \\
$\quad$ Rising plate meter height $(1 \mathrm{unit}=5 \mathrm{~mm})$ & $27.2 \pm 5.5$ \\
Pasture yield $(\mathrm{kg} \mathrm{DM} / \mathrm{ha})$ & $2185 \pm 483$ \\
$\quad$ Pasture allowance $(\mathrm{kg} \mathrm{DM} / \mathrm{cow} / \mathrm{d})$ & $11.1 \pm 1.3$ \\
Post-grazing & \\
Rising plate meter height $(1 \mathrm{unit}=5 \mathrm{~mm})$ & $10.1 \pm 1.4$ \\
Pasture yield $(\mathrm{kg} \mathrm{DM} / \mathrm{ha})$ & $692 \pm 124$ \\
$\quad$ Pasture removed $(\mathrm{kg} \mathrm{DM} / \mathrm{ha})$ & $1493 \pm 446$ \\
Estimated pasture intake $(\mathrm{kg} \mathrm{DM} / \mathrm{cow} / \mathrm{d})$ & $7.55 \pm 1.44$
\end{tabular}

Pasture yield, pasture allowance and estimated pasture group intake above $30 \mathrm{~mm}$ ground level determined using the linear regression: $\mathrm{Y}=87.63 \times \mathrm{H}-195.11\left(\mathrm{R}^{2}=0.86\right)$, where $\mathrm{Y}=$ pasture yield, and $\mathrm{H}=$ rising plate meter height 
Table 3 Composition of treatment concentrates, palm kernel expeller source and pasture available to lactating Jersey cows

\begin{tabular}{|c|c|c|c|c|c|c|}
\hline \multirow{2}{*}{$\begin{array}{l}\text { Ingredient } \\
\text { (g/kg DM) }\end{array}$} & \multicolumn{4}{|c|}{ Treatment concentrate $(n=4)$} & \multirow{2}{*}{$\begin{array}{c}\text { PKE } \\
(n=1)\end{array}$} & \multirow{2}{*}{$\begin{array}{c}\text { Pasture } \\
(n=7)\end{array}$} \\
\hline & PKE0 $^{1}$ & PKE10 & PKE20 & PKE30 & & \\
\hline DM (as is) & $902 \pm 5.5$ & $905 \pm 4.9$ & $903 \pm 3.1$ & $913 \pm 4.8$ & 910 & $140 \pm 18.1$ \\
\hline OM & $935 \pm 4.0$ & $943 \pm 0.7$ & $942 \pm 0.8$ & $939 \pm 2.0$ & 956 & $889 \pm 9.7$ \\
\hline IVOMD & $953 \pm 4.6$ & $955 \pm 6.0$ & $924 \pm 6.2$ & $847 \pm 14.8$ & 312 & $646 \pm 63.3$ \\
\hline GE (MJ/kg) & $17.6 \pm 0.2$ & $17.8 \pm 0.2$ & $17.9 \pm 0.2$ & $18.2 \pm 0.1$ & 21.3 & $17.9 \pm 0.4$ \\
\hline $\mathrm{ME}(\mathrm{MJ} / \mathrm{kg})^{2}$ & $14.1 \pm 0.2$ & $14.2 \pm 0.2$ & $13.9 \pm 0.2$ & $12.9 \pm 0.2$ & 5.57 & $9.36 \pm 0.93$ \\
\hline$N F C^{3}$ & $658 \pm 1.4$ & $652 \pm 5.4$ & $594 \pm 7.3$ & $547 \pm 10.2$ & 134 & $116 \pm 23.3$ \\
\hline $\mathrm{CP}$ & $141 \pm 3.2$ & $140 \pm 1.7$ & $140 \pm 1.6$ & $139 \pm 0.7$ & 165 & $232 \pm 38.6$ \\
\hline CP:ME ratio & $1.01 \pm 0.03$ & $0.99 \pm 0.02$ & $1.01 \pm 0.01$ & $1.08 \pm 0.02$ & 2.97 & $2.50 \pm 0.47$ \\
\hline NDF & $104 \pm 1.6$ & $112 \pm 4.8$ & $173 \pm 10.5$ & $208 \pm 11.3$ & 543 & $514 \pm 31.4$ \\
\hline ADF & $54.2 \pm 1.7$ & $54.4 \pm 2.7$ & $93.9 \pm 5.5$ & $117 \pm 8.9$ & 35.6 & $286 \pm 19.3$ \\
\hline$A D L$ & $15.9 \pm 1.1$ & $14.3 \pm 1.6$ & $27.0 \pm 2.3$ & $34.1 \pm 3.5$ & 94.9 & $47.1 \pm 5.9$ \\
\hline NDIN & $12.6 \pm 0.6$ & $13.3 \pm 0.2$ & $15.4 \pm 0.5$ & $16.5 \pm 0.5$ & 22.6 & $18.0 \pm 4.4$ \\
\hline ADIN & $20.7 \pm 1.7$ & $20.2 \pm 1.1$ & $17.7 \pm 0.9$ & $15.6 \pm 0.5$ & 14.4 & $6.35 \pm 1.37$ \\
\hline Crude fat & $31.7 \pm 3.1$ & $36.7 \pm 4.6$ & $42.7 \pm 3.4$ & $51.8 \pm 4.6$ & 113 & $27.9 \pm 5.7$ \\
\hline $\mathrm{Ca}$ & $11.3 \pm 0.6$ & $11.2 \pm 0.6$ & $11.2 \pm 0.6$ & $12.0 \pm 0.5$ & 6.59 & $4.78 \pm 0.49$ \\
\hline$P$ & $5.66 \pm 0.21$ & $5.22 \pm 0.12$ & $5.25 \pm 0.09$ & $5.30 \pm 0.04$ & 7.91 & $5.73 \pm 0.50$ \\
\hline $\mathrm{Ca}: \mathrm{P}$ ratio & $2.00 \pm 0.07$ & $2.15 \pm 0.08$ & $2.14 \pm 0.07$ & $2.27 \pm 0.11$ & 0.83 & $0.85 \pm 0.15$ \\
\hline $\mathrm{Mg}$ & $3.58 \pm 0.11$ & $3.50 \pm 0.16$ & $3.43 \pm 0.10$ & $3.76 \pm 0.23$ & 3.85 & $6.90 \pm 0.89$ \\
\hline K & $10.1 \pm 0.3$ & $10.2 \pm 0.2$ & $9.60 \pm 0.11$ & $9.64 \pm 0.17$ & 8.99 & $42.6 \pm 6.5$ \\
\hline $\mathrm{Na}$ & $6.44 \pm 0.99$ & $3.47 \pm 0.20$ & $3.16 \pm 0.09$ & $3.23 \pm 0.09$ & 0.051 & $1.39 \pm 0.49$ \\
\hline $\mathrm{Cu}$ & $0.026 \pm 0.001$ & $0.032 \pm 0.002$ & $0.034 \pm 0.004$ & $0.034 \pm 0.003$ & 0.024 & $0.010 \pm 0.002$ \\
\hline
\end{tabular}

Mean \pm SD

${ }_{1}^{1}$ PKE: palm kernel expeller; PKE0: concentrate containing $0 \mathrm{~g}$ PKE/kg DM; PKE10: concentrate containing $100 \mathrm{~g}$ PKE/kg DM; PKE20: concentrate containing 200 g PKE/kg DM; PKE30: concentrate containing 300 g PKE/kg DM

$2 \mathrm{ME}$ : metabolizable energy, calculated: $\mathrm{ME}_{\text {concentrate }}=0.84 \times \mathrm{GE} \times$ IVOMD and $\mathrm{ME}_{\text {pasture }}=0.81 \times \mathrm{GE} \times$ IVOMD (MAFF, 1984).

${ }^{3}$ NFC: non-fibre carbohydrate, calculated: NFC $=[100-($ NDF + ash + CP + crude fat $)]$

The average milk yield from cows offered the PKE30 concentrate was lower $(P=0.046)$ than that of cows offered the PKEO concentrate (Table 4). Milk yield decreased linearly from $15.6 \mathrm{~kg} / \mathrm{cow}$ per day in PKE0 to $14.3 \mathrm{~kg} / \mathrm{cow}$ per day in PKE30 $(P<0.05)$. Cows fed the PKE20 and PKE30 concentrates had a higher $(P<0.01)$ milk fat content compared with that of cows fed the PKEO concentrate and overall milk fat content increased linearly from cows on PKE0 to PKE30 $(P<0.01)$. Despite this, fat yields and fat corrected milk were similar for cows fed the PKE0, PKE10, PKE20, and PKE30 concentrates. Protein yield increased quadratically across treatments $(P<0.05)$. Protein to fat ratio decreased linearly from 0.78 in PKE0 to 0.72 in PKE30 $(P<0.01)$ with cows on PKE30 having a lower protein to fat ratio than that of cows on PKE0 and PKE10 $(P<0.05)$. Milk urea nitrogen content was the highest $(P<0.01)$ for cows offered the PKE30 concentrate in comparison with the contents of this component from cows offered the PKE0 and PKE10 concentrate. Overall, MUN and SCC increased linearly from cows on PKEO to PKE30 $(P<0.01)$. Cows fed the PKE10 and PKE20 concentrates lost body condition $(P<0.01)$, while cows fed the PKE0 concentrate gained body condition. Body condition change decreased linearly and quadratically from +0.09 in PKE0 to 0.07 in PKE30 $(P<0.05)$. Regardless of this, the bodyweight of cows was unaffected by PKE supplementation.

The diurnal patterns of ruminal $\mathrm{pH}$ (Figure 1) were similar for cows offered all concentrates. No dietary effect $(P>0.05)$ was detected on the mean diurnal ruminal $\mathrm{pH}$ of cows offered PKE0, PKE10, PKE20 and 
PKE30 concentrates: $6.44,6.53,6.52$ and 6.50 , respectively. Ruminal pH of cows decreased after concentrate was fed (Figure 1).

Table 4 Effects on production parameters of various feeding levels of palm kernel expeller in grazing Jersey cows

\begin{tabular}{|c|c|c|c|c|c|c|c|c|}
\hline \multirow{2}{*}{ Parameter } & \multicolumn{4}{|c|}{ Treatment concentrate } & \multirow{2}{*}{ SEM } & \multicolumn{3}{|c|}{$P$-value } \\
\hline & PKE0 $^{1}$ & PKE10 & PKE20 & PKE30 & & Con & Lin & Quad \\
\hline \multicolumn{9}{|l|}{ Milk production (kg/cow/d) } \\
\hline Milk yield & $15.6^{\mathrm{a}}$ & $15.4^{\mathrm{ab}}$ & $15.3^{\mathrm{ab}}$ & $14.3^{\mathrm{b}}$ & 0.45 & 0.046 & 0.01 & 0.24 \\
\hline Fat corrected milk ${ }^{2}$ & 17.0 & 17.4 & 17.7 & 17.0 & 0.37 & 0.37 & 0.92 & 0.09 \\
\hline Fat yield & 0.72 & 0.75 & 0.77 & 0.75 & 0.016 & 0.12 & 0.08 & 0.09 \\
\hline Protein yield & 0.56 & 0.58 & 0.57 & 0.54 & 0.013 & 0.052 & 0.22 & 0.01 \\
\hline \multicolumn{9}{|l|}{ Milk composition (g/kg) } \\
\hline Fat & $46.3^{\mathrm{c}}$ & $49.3^{\mathrm{abc}}$ & $50.6^{\mathrm{ab}}$ & $52.9^{\mathrm{a}}$ & 1.25 & $<0.01$ & $<0.01$ & 0.73 \\
\hline Protein & 35.8 & 37.7 & 37.5 & 37.6 & 0.64 & 0.10 & 0.07 & 0.15 \\
\hline Protein to fat ratio & $0.78^{\mathrm{a}}$ & $0.77^{\mathrm{a}}$ & $0.74^{\mathrm{ab}}$ & $0.72^{\mathrm{b}}$ & 0.013 & 0.01 & $<0.01$ & 0.54 \\
\hline Lactose & 45.0 & 45.7 & 45.0 & 45.2 & 0.33 & 0.45 & 0.90 & 0.53 \\
\hline Milk urea nitrogen (mg/dL) & $12.0^{\mathrm{c}}$ & $12.2^{\mathrm{bc}}$ & $12.7^{\mathrm{abc}}$ & $13.2^{\mathrm{a}}$ & 0.21 & $<0.01$ & $<0.01$ & 0.48 \\
\hline Somatic cell count $\left(\times 10^{3}\right.$ cells $\left./ \mathrm{mL}\right)$ & 134 & 184 & 211 & 188 & 19.9 & 0.057 & $<0.01$ & 0.06 \\
\hline \multicolumn{9}{|l|}{ Body weight (kg) } \\
\hline Before & 418 & 416 & 399 & 410 & 7.4 & 0.26 & 0.22 & 0.36 \\
\hline After & 415 & 416 & 395 & 407 & 6.7 & 0.12 & 0.15 & 0.47 \\
\hline Change & -1.13 & +0.64 & -3.39 & -3.11 & 3.640 & 0.85 & 0.54 & 0.84 \\
\hline \multicolumn{9}{|l|}{ Body condition score (scale 1 to 5 ) } \\
\hline Before & 2.19 & 2.25 & 2.22 & 2.19 & 0.039 & 0.70 & 0.87 & 0.29 \\
\hline After & $2.28^{\mathrm{a}}$ & $2.09^{b}$ & $2.02^{\mathrm{b}}$ & $2.12^{\mathrm{b}}$ & 0.037 & $<0.01$ & $<0.01$ & $<0.01$ \\
\hline Change & $+0.09^{\mathrm{a}}$ & $-0.16^{\mathrm{b}}$ & $-0.20^{\mathrm{b}}$ & $-0.07^{\mathrm{ab}}$ & 0.047 & $<0.01$ & 0.02 & $<0.01$ \\
\hline
\end{tabular}

The rumen contents from cows fed the concentrate containing PKE spent less time $(P=0.001)$ below a ruminal $\mathrm{pH}$ of 6.0 than their counterparts that were offered the PKE0 concentrate (Table 5). Overall, time spent below ruminal pH 6.2 and 6.0 decreased quadratically from cows on PKEO to PKE30 $(P<0.01)$. Related to this, cows fed concentrate containing PKE spent zero time below a ruminal $\mathrm{pH}$ of 5.8 , whereas cows fed the PKE0 concentrate spent $1.69 \mathrm{~h}$ below a ruminal $\mathrm{pH}$ of 5.8 .

The ruminal fluid constituents of cows fed increasing levels of PKE were unaffected by dietary treatment: ammonia- $\mathrm{N}, \mathrm{pH}$ and total VFA concentration (Table 6). However, the ruminal fluid from cows offered PKE30 concentrate yielded a greater $(P=0.04)$ molar percentage of iso-butyric acid than cows offered the PKE0 concentrate and a positive linear relationship was evident from PKE0 to PKE30 $(P<0.05)$. The molar percentages of acetic, propionic, and butyric acid were unaffected by dietary treatment. 


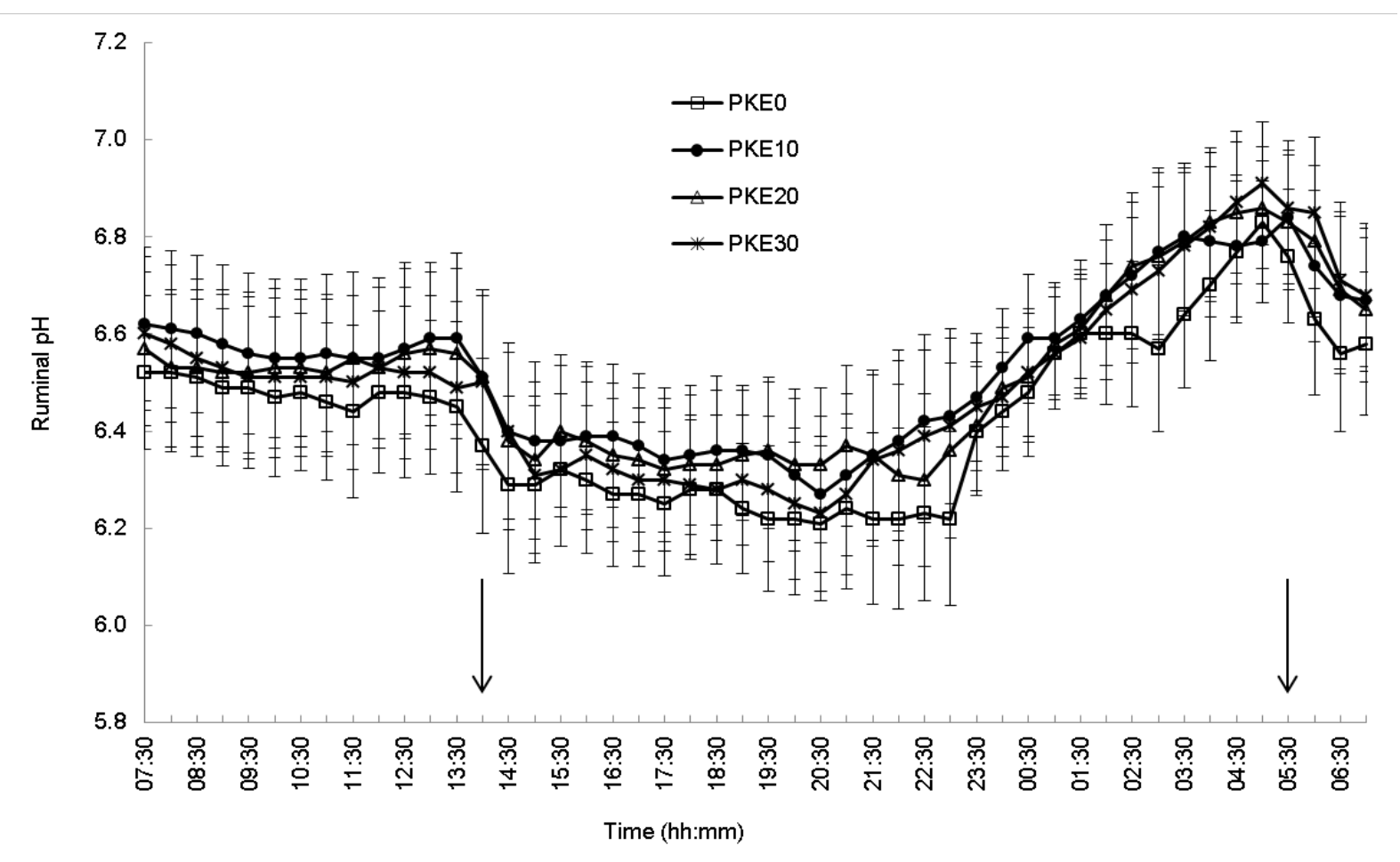

Figure 1 Effects on diurnal ruminal $\mathrm{pH}$ of various feeding levels of palm kernel expeller in grazing Jersey cows

Arrows indicate when concentrate was fed and error bars indicate SEM

Table 5 Effects of various feeding levels of palm kernel expeller on hours spent diurnally below a ruminal pH of $6.2,6.0$ and 5.8 in grazing Jersey cows

\begin{tabular}{|c|c|c|c|c|c|c|c|c|}
\hline \multirow{2}{*}{ Parameter } & \multicolumn{4}{|c|}{ Treatment concentrate } & \multirow{2}{*}{ SEM } & \multicolumn{3}{|c|}{$P$-value } \\
\hline & $\mathrm{PKE}^{1}$ & PKE10 & PKE20 & PKE30 & & Con & Lin & Quad \\
\hline \multicolumn{9}{|l|}{ Ruminal $\mathrm{pH}$} \\
\hline$<6.2$ & 4.56 & 2.50 & 1.75 & 4.00 & 1.541 & 0.55 & nd & $<0.01$ \\
\hline$<6.0$ & $2.13^{\mathrm{a}}$ & $0.13^{b}$ & $0.06^{\mathrm{b}}$ & $0.31^{\mathrm{b}}$ & 0.266 & 0.001 & nd & $<0.01$ \\
\hline$<5.8$ & 1.69 & 0 & 0 & 0 & $\mathrm{nd}^{2}$ & nd & nd & nd \\
\hline
\end{tabular}

DM and NDF degradability decreased $(P<0.05)$ for cows on the PKE30 concentrate in comparison with that of cows fed the PKE0 concentrate at both the 18 and $30 \mathrm{~h}$ ruminal incubation intervals (Table 7). Furthermore, the rate of NDF degradability was negatively $(P<0.05)$ affected at both the 18 and $30 \mathrm{~h}$ ruminal incubation interval and the mean of the ruminal incubation period for cows offered the PKE30 concentrate in contrast to cows fed the PKEO concentrate. A quadratic decrease in NDF degradability and its rate were observed across treatments at the 6-hour incubation interval $(P<0.05)$, whereas a linear decrease was evident at both the 18- and 30-hour incubation intervals for DM and NDF degradability as well as the rate of NDF degradability (and mean) from PKE0 to PKE30 $(P<0.05)$. 
Table 6 Effects of various feeding levels of palm kernel expeller on rumen fluid $\mathrm{pH}$ and concentrations of rumen fluid constituents in grazing Jersey cows

\begin{tabular}{|c|c|c|c|c|c|c|c|c|}
\hline \multirow{2}{*}{ Parameter } & \multicolumn{4}{|c|}{ Treatment concentrate } & \multirow{2}{*}{ SEM } & \multicolumn{3}{|c|}{$P$-value } \\
\hline & $\mathrm{PKE}^{1}$ & PKE10 & PKE20 & PKE30 & & Con & Lin & Quad \\
\hline \multicolumn{9}{|l|}{ Rumen fluid ${ }^{2}$} \\
\hline $\mathrm{pH}$ & 6.00 & 6.02 & 5.97 & 5.93 & 0.036 & 0.44 & 0.18 & 0.41 \\
\hline $\mathrm{NH}_{3}-\mathrm{N}(\mathrm{mg} / \mathrm{dL})$ & 18.3 & 17.1 & 17.1 & 17.5 & 0.92 & 0.75 & 0.58 & 0.36 \\
\hline Total VFA (mmol/L) & 148 & 149 & 144 & 147 & 2.5 & 0.58 & 0.48 & 0.80 \\
\hline \multicolumn{9}{|l|}{ Individual VFA (mmol \%) } \\
\hline Acetic acid & 69.6 & 69.8 & 70.4 & 69.7 & 0.22 & 0.12 & 0.33 & 0.08 \\
\hline Propionic acid & 21.8 & 21.4 & 21.2 & 21.4 & 0.20 & 0.27 & 0.18 & 0.17 \\
\hline Butyric acid & 4.01 & 4.05 & 4.02 & 3.98 & 0.064 & 0.88 & 0.71 & 0.52 \\
\hline Iso-butyric acid & $3.55^{\mathrm{b}}$ & $3.59^{\mathrm{ab}}$ & $3.57^{\mathrm{ab}}$ & $3.70^{\mathrm{a}}$ & 0.034 & 0.04 & 0.01 & 0.27 \\
\hline Valeric acid & $1.13^{\mathrm{ab}}$ & $1.12^{\mathrm{ab}}$ & $1.08^{\mathrm{b}}$ & $1.17^{\mathrm{a}}$ & 0.018 & 0.02 & 0.25 & 0.02 \\
\hline Acetic to propionic acid ratio & 3.21 & 3.27 & 3.34 & 3.26 & 0.038 & 0.17 & 0.23 & 0.08 \\
\hline
\end{tabular}

${ }^{a, b}$ Row means with different superscripts differ significantly at $P<0.05$; Con: contrast; Lin: linear; Quad: quadratic

${ }^{1}$ PKE: palm kernel expeller; PKE0: concentrate containing $0 \mathrm{~g}$ PKE/kg DM; PKE10: concentrate containing $100 \mathrm{~g}$ PKE/kg DM; PKE20: concentrate containing 200 g PKE/kg DM; PKE30: concentrate containing 300 g PKE/kg DM

${ }^{2} \mathrm{NH}_{3}-\mathrm{N}$ : ammonia-nitrogen; VFA: volatile fatty acid

Table 7 Effects of various feeding levels of palm kernel expeller on in situ dry matter degradability, neutral detergent fibre degradability and rate of neutral detergent fibre degradability of the available pasture in grazing Jersey cows

\begin{tabular}{|c|c|c|c|c|c|c|c|c|}
\hline \multirow{2}{*}{ Parameter (coefficient) ${ }^{2}$} & \multicolumn{4}{|c|}{ Treatment concentrate } & \multirow{2}{*}{ SEM } & \multicolumn{3}{|c|}{$P$-value } \\
\hline & $\mathrm{PKEO}^{1}$ & PKE10 & PKE20 & PKE30 & & Con & Lin & Quad \\
\hline \multicolumn{9}{|l|}{ DM degradability } \\
\hline \multicolumn{9}{|l|}{ Incubation period $(\mathrm{h})$} \\
\hline 6 & 0.29 & 0.29 & 0.30 & 0.29 & 0.004 & 0.37 & 0.41 & 0.21 \\
\hline 18 & $0.44^{\mathrm{a}}$ & $0.43^{\mathrm{ab}}$ & $0.42^{\mathrm{ab}}$ & $0.41^{\mathrm{b}}$ & 0.007 & 0.04 & $<0.01$ & 0.98 \\
\hline 30 & $0.57^{\mathrm{a}}$ & $0.57^{\mathrm{a}}$ & $0.55^{\mathrm{ab}}$ & $0.53^{\mathrm{b}}$ & 0.009 & 0.01 & $<0.01$ & 0.31 \\
\hline \multicolumn{9}{|l|}{ NDF degradability } \\
\hline \multicolumn{9}{|l|}{ Incubation period (h) } \\
\hline 6 & 0.09 & 0.10 & 0.11 & 0.08 & 0.006 & 0.10 & 0.61 & 0.03 \\
\hline 18 & $0.27^{\mathrm{a}}$ & $0.27^{\mathrm{a}}$ & $0.26^{\mathrm{ab}}$ & $0.23^{\mathrm{b}}$ & 0.007 & $<0.01$ & $<0.01$ & 0.05 \\
\hline 30 & $0.44^{\mathrm{a}}$ & $0.44^{\mathrm{a}}$ & $0.42^{\mathrm{a}}$ & $0.37^{\mathrm{b}}$ & 0.011 & $<0.01$ & $<0.01$ & 0.06 \\
\hline \multicolumn{9}{|c|}{ Rate of NDF degradability ${ }^{3}$} \\
\hline \multicolumn{9}{|l|}{ Incubation period (h) } \\
\hline 6 & 0.019 & 0.020 & 0.022 & 0.017 & 0.0013 & 0.15 & 0.71 & 0.04 \\
\hline 18 & $0.023^{\mathrm{a}}$ & $0.023^{\mathrm{ab}}$ & $0.021^{\mathrm{ab}}$ & $0.020^{\mathrm{b}}$ & 0.0008 & 0.04 & $<0.01$ & 0.55 \\
\hline 30 & $0.026^{a}$ & $0.025^{a}$ & $0.023^{\mathrm{ab}}$ & $0.020^{\mathrm{b}}$ & 0.0010 & $<0.01$ & $<0.01$ & 0.33 \\
\hline Mean & $0.023^{\mathrm{a}}$ & $0.023^{\mathrm{a}}$ & $0.022^{\mathrm{a}}$ & $0.019^{b}$ & 0.0004 & $<0.01$ & $<0.01$ & $<0.01$ \\
\hline
\end{tabular}

$\overline{a, b}$ Row means with different superscripts differ significantly at $P<0.05$; Con: contrast; Lin: linear; Quad: quadratic

${ }^{1}$ PKE: palm kernel expeller; PKEO: concentrate containing $0 \mathrm{~g}$ PKE/kg DM; PKE10: concentrate containing $100 \mathrm{~g}$ PKE/kg DM; PKE20: concentrate containing 200 g PKE/kg DM; PKE30: concentrate containing 300 g PKE/kg DM

${ }^{2}$ DM: dry matter; NDF: neutral detergent fibre

${ }^{3}$ Unit per hour 


\section{Discussion}

It has been comprehensively documented that pasture quality is one of several factors that may affect milk response to supplementation (Bargo et al., 2003). The ME, CP, and NDF contents of the kikuyuryegrass pasture in the current study were similar to those of Van der Colf et al. (2015), as reported in the second year of establishment during the summer season. As expected, the IVOMD was 20\% lower (646 versus $802 \mathrm{~g} / \mathrm{kg} \mathrm{DM}$ ), ME content was 19\% lower (9.36 versus $11.5 \mathrm{MJ} / \mathrm{kg} \mathrm{DM}$ ) and the NDF content was 4\% higher (514 versus $494 \mathrm{~g} / \mathrm{kg} \mathrm{DM}$ ) for the study pasture in comparison with similar pasture during spring (Van Wyngaard et al., 2015). Therefore, it is plausible that pasture in the current study was of lower quality.

In the current study, the summer pasture induced results that indicated that milk fat content and milk yield were affected by the amount of PKE supplementation. Cows on the PKE30 concentrate produced less milk than cows on PKE0, PKE10 or PKE20. Cows offered the PKE20 or PKE30 concentrate had a higher milk fat content than cows offered PKEO. Consequently, for early lactation cows on low-quality pasture, the authors accept their first hypothesis that feeding dairy concentrate containing PKE would increase their milk fat content. They accept their second hypothesis that feeding dairy concentrate containing 100 and $200 \mathrm{~g}$ $\mathrm{PKE} / \mathrm{kg} \mathrm{DM}$ to early lactation cows on low-quality pasture would maintain their milk yield. However, this hypothesis is rejected when concentrate containing $300 \mathrm{~g} \mathrm{PKE} / \mathrm{kg} \mathrm{DM}$ is fed to cows because of the observed decrease in milk yield. The milk fat content finding in the current study agrees with the findings of Davison et al. (1994) in which the inclusion of 400 and $600 \mathrm{~g} \mathrm{PKE} / \mathrm{kg} \mathrm{DM}$, replacing grain concentrate, in a supplemental feed in the diet of dairy cows increased milk fat content with no detrimental effect on milk yield. In contrast, the milk yield finding in the current study disagrees with that of Davison et al. (1994). In that study, cows grazed a low allowance of pasture and were offered $9 \mathrm{~kg}$ DM maize silage during the night in a feed pad without pasture. The ME supply was adequate because of the substitution of pasture with maize silage, whereas ME supply was limited in the current study for cows fed the PKE30 concentrate owing to the combination of the low fibre degradable and ME containing summer pasture and low ME content of the PKE. This assumption is supported by Kolver \& Muller (1998) who stated that energy supply is the first limiting factor for milk production on pasture-based systems. The milk response of $-1.3 \mathrm{~kg} /$ day for cows on the PKE30 concentrate corresponds to the milk response range of -2.6 to $1.3 \mathrm{~kg} / \mathrm{day}$, as reported by Bargo et al. (2003), when a starch-based concentrate was replaced with a fibre-based concentrate on pasture.

Although the milk yield for cows offered the PKE30 concentrate decreased, their milk fat content and that of cows offered the PKE20 concentrate were increased. A positive milk fat content response was also observed by Dias et al. (2008) when cows were fed a restricted pasture allowance supplemented with 3 and $6 \mathrm{~kg} / \mathrm{cow} / \mathrm{d}$ PKE. Dias et al. (2008) also reported a positive milk yield response when cows were supplemented with PKE compared with cows grazing restricted pasture allowance without PKE supplementation. The reason for the positive milk yield response, however, was due solely to an ME shortage being amended with supplementation. In the current study there are three possible reasons for the increase in milk fat content: i) NDF intake, ii) fat intake, and iii) both NDF and fat intake. The increase in total dietary NDF content due to PKE inclusion is small compared with the increase in total dietary fat content. In addition, the NDF of PKE is expected to be low in effective fibre because of PKE being ground to meal form. According to Zibeline et al. (2008) it is the effective fibre that affects milk fat content. Thus, the NDF intake in the current study probably explained the observed milk fat content response to a lesser extent than fat intake. The fat contained in PKE is very high in short- and medium-chain saturated fatty acids (Dias et al., 2008), which can increase milk fat content when supplemented to dairy cows (Shroeder et al., 2004). In the current study, milk fat content increased by 9.3 and 14.3 percentage units for cows offered the PKE20 and PKE30 concentrates, respectively, in comparison with cows fed the PKE0. This is in agreement with Schroeder et al. (2004), who found that saturated fatty acid supplementation increased milk fat content by 5.1\% (range: -2.5 to $15 \%$ ) when compared with control groups in a review that involved 17 comparisons. The authors can therefore assume that fat intake in the form of saturated fatty acids, influenced by PKE inclusion in the concentrate, contributed more to the increase in milk fat content observed in the current study than NDF intake.

Fat supplementation not only increases milk fat content in pasture-based systems, but may impede pasture NDF degradability (Jenkins, 1993), hence, a decrease in DM intake and milk production. As such, the DM and NDF degradability and the milk yield were inhibited for cows fed the PKE30 concentrate. The dietary fat content of cows on the PKE30 diet was only $37.9 \mathrm{~g} / \mathrm{kg}$, which is far below the threshold of $>80-90$ $\mathrm{g} / \mathrm{kg}$ dietary fat, which may inhibit rumen fibre degradability (Schroeder et al., 2004). The authors can therefore assume that dietary fat was not exclusively responsible for the reduced fibre degradability observed in the current study. The lower ME content of the PKE30 concentrate could have contributed to the reduced fibre degradability, because energy is one of the limiting factors for microbial activity. It is plausible that the combination of high fat and low ME content restricts the supplementation rate of PKE to avoid a decrease in rumen fibre degradation, hence milk production. 
Ruminal fibre degradability is influenced not only by fat supplementation, but by ruminal $\mathrm{pH}$ as well. The diurnal ruminal $\mathrm{pH}$ of cows offered concentrate containing PKE was 1) within the optimal range for ruminal fibre digestion on pasture systems (ruminal pH >5.8) (Kolver \& De Veth, 2002), 2) spent less h/day below a ruminal $\mathrm{pH}$ of 6.0 and 3) spent zero h/day below a ruminal $\mathrm{pH}$ of 5.8 than cows fed concentrate without PKE. Even though the ruminal $\mathrm{pH}$ of cows fed the PKE30 concentrate was at optimum levels, ruminal fibre degradability was reduced.

Similar to ruminal $\mathrm{pH}$ and ruminal fibre degradability, ruminal fermentation components, such as VFA, are good indicators of rumen health and for detecting a response to dietary alterations. It has been reported that VFA such as iso-acids and valeric acid enhanced in vitro cellulose digestion (Gorosito et al., 1985). In the current study concentrates containing PKE had no effect on total VFA concentrations and trivial effects on the molar percentages of iso-butyric and valeric acid. The increase in iso-acids with PKE supplementation was also observed by Abdullah \& Hutagalung (1988), although this was with beef cattle.

Propionic acid and, more distinctly, butyric acid are strongly related to milk response and DM intake (Seymour et al., 2005). In the current study, group DM intake was estimated rather than individual intake. This is one of the major disadvantages of pasture-based studies (Bargo et al., 2003). Nonetheless, the authors can say that cows received adequate pasture owing to the observed pasture post-grazing height that was within the range of 50-60 mm above ground level, indicating that summer kikuyu-based pasture was not over- or under-utilised (Fulkerson et al., 1999). Furthermore, protein supply was sufficient in all treatment diets due to ruminal ammonia-N remaining above $5 \mathrm{mg} / \mathrm{dL}$ (Satter \& Slyter, 1974) and MUN remaining within the range of $10-40 \mathrm{mg} / \mathrm{dL}$ as reported by Bargo et al. (2003) in a review article.

Milk components such as milk protein and milk lactose content were unaffected by PKE supplementation, which is in agreement with previous studies supplementing PKE (Carvallo et al., 2006; Dias et al., 2008; Van Wyngaard et al., 2015). However, Van Wyngaard et al. (2015) reported an increase in milk lactose content at a $400 \mathrm{~g} \mathrm{PKE} / \mathrm{kg}$ of DM inclusion rate. It has been suggested that MUN increases as the diet CP : ME ratio increases (Roseler et al., 1993). In Table 3, it is evident that the CP : ME ratios across treatment concentrates are very similar, albeit a linear increase in MUN are observed across treatments. The available pasture had more than double the $\mathrm{CP}$ : ME ratio than that of the various treatment concentrates (2.5 versus 1). Therefore, the linear increase in MUN across treatment groups could be ascribed to a possible step-wise increase in pasture intake as the level of PKE increased in the concentrate. The observed linear increase in SCC with increased PKE inclusion has no biological impact, as all SCC values fall well below the specified value of $300 \times 10^{3}$ cells per $\mathrm{mL}$ of milk, which is the threshold for sub-clinical mastitis (De Villiers et al., 2000).

The low values in bodyweight change observed in the current study reflect the early lactation of the cows where energy intake is partitioned to milk production rather than towards body reserves (Garnsworthy, 1997). Metabolisable energy calculations on the treatment diets showed that cows on the concentrates containing PKE were subject to an ME intake of up to $4.4 \%$ lower than that of cows fed the PKE0 concentrate. The change in BCS reflects the amount of energy consumed by cows on the PKE10 and PKE20 containing concentrates in contrast to cows fed the PKEO concentrate. Metabolisable energy was by far the lowest for PKE30, whereas this had no effect on BCS change. This can only be ascribed to within animal variation, because the after BCS of cows on PKE30 was lower than that of cows on PKE0.

The increase in milk fat content for cows fed the PKE20 concentrate may result in an added economical advantage, depending on the milk payment programme. The lack of a significant effect on milk fat yield and the negative linear relationship with milk protein to milk fat ratio and PKE inclusion may be unfavourable for certain milk payment programmes. However, the numerical increase of $7 \%$ milk fat yield with PKE20 as opposed to PKEO was comparable with that of milk fat content (+9\% for PKE20 versus PKE0) and might be of practical importance despite the lack for a significant effect.

\section{Conclusion}

The inclusion of 200 and $300 \mathrm{~g} \mathrm{PKE} / \mathrm{kg}$ of DM in a dairy concentrate fed to early lactation Jersey cows grazing summer kikuyu-based pasture increased their milk fat content. Feeding $200 \mathrm{~g} \mathrm{PKE/kg} \mathrm{DM} \mathrm{sustained}$ milk yield, whereas feeding $300 \mathrm{~g} \mathrm{PKE} / \mathrm{kg}$ of DM decreased milk yield. It was believed that the fat intake in the form of saturated fatty acids, influenced by PKE inclusion in the concentrate, contributed more to the increase in milk fat content than NDF intake. Furthermore, the decrease in milk yield was associated with the change in ruminal fibre degradability. A possible economical advantage, gained from the increase in milk fat content, depends on the milk payment system. 


\section{Acknowledgements}

This research was supported and funded by the Western Cape Department of Agriculture and the Western Cape Agricultural Research Trust. The milking team and technical staff at Outeniqua Research Farm need special acknowledgement; it would not have been possible without their support.

\section{Author's Contributions}

Conception and design: JDV; data collection, analyses and drafting of paper: JDV; critical revision: JDV \& RM; critical revision and final approval of version to be published: JDV \& RM

\section{Conflict of Interest Declaration}

The authors declare that they have no competing interests.

\section{References}

Abdullah, N. \& Hutagalung, R.I., 1988. Rumen fermentation, urease activity and performance of cattle given palm kernel cake-based diet. Anim. Feed Sci. Technol. 20, 79-86.

Agri Laboratory Association of Southern Africa (AgriLASA), 1998. Feed and plant analysis methods. AgriLASA, Pretoria, South Africa.

ARC-ISCW, 2011. Agro-Climatology database. Agricultural Research Council-Institute for Soil Climate and Water, Pretoria, South Africa.

Association of Official Analytical Chemists (AOAC), 2000. Official methods of analysis, 17th edition. AOAC, Gaithersburg, MD, USA.

Bargo, F., Muller, L.D., Kolver, E.S. \& Delahoy, J.E., 2003. Invited review: Production and digestion of supplemented dairy cows on pasture. J. Dairy Sci. 86, 1-42.

Broderick, G.A. \& Kang, J.H., 1980. Automated simultaneous determination of ammonia and total amino acids in ruminal fluid and in vitro media. J. Dairy Sci. 63, 64-75.

Carvalho, L.P.F., Cabritta, A.R.J., Dewhurst, R.J., Vicente, T.E.J., Lopes, Z.M.C. \& Fonseca, A.J.M., 2006. Evaluation of palm kernel meal and corn distillers grains in corn silage-based diets for lactating dairy cows. J. Dairy Sci. 89, 2705-2715.

Chin, F.Y., 2001. Palm kernel cake (PKC) as a supplement for fattening and dairy cattle in Malaysia. In Forage development in Southeast Asia: Strategies and impacts. 7th Meeting of the regional working group on grazing and feed resources, FAO, Rome, Italy.

Coetzee, K., 2016a. Lacto Data, volume 19. Milk SA, Milk Producers' Organisation, Pretoria, South Africa.

Coetzee, K., 2016b. Dairy market trends, April 2016. Milk SA, Milk Producers' Organisation, Pretoria, South Africa.

Cruywagen, C.W., 2006. Technical note: A method to facilitate the retrieval of polyester bags used in in sacco trials in ruminants. J. Dairy Sci. 89, 1028-1030.

Davison, T.M., Ehrlich, W.K., Orr, W.N. \& Ansell, J., 1994. Palm kernel expeller as a substitute for grain in dairy cow rations. Proceedings of the 20th biennial conference of the Australian Society of Animal Production, July 1994, Perth, Western Australia, pp. 372

De Villiers, P., Petzer, I.M. \& Erasmus, L., 2000. Chapter 8: The use of milk recording information as a herd management tool. In: Dairy Herd Improvement in South Africa. ARC - Animal Improvement Institute, Irene, RSA.

Dias, F.N., 2010. Supplementation of palm kernel expeller to grazing dairy farms in New Zealand. PhD thesis, Massey University, Palmerston North, New Zealand.

Dias, F.N., Burke, J., Pacheco, D. \& Holmes, C.W., 2008. Brief communication: The effect of palm kernel expeller as a supplement for grazing dairy cows at the end of lactation. Proceedings of the 68th conference of the New Zealand Society of Animal Production, January 2008, Brisbane, Australia, pp. 111-112.

Fulkerson, W.J., Slack, K. \& Havilah, E., 1999. The effect of defoliation interval and height on growth and herbage quality of kikuyu grass (Pennisetum clandestinum). Trop. Grasslands 33, 138-145.

Gaines, W.L., 1928. The energy basis of measuring milk yield in dairy cows, Bulletin 308. Agricultural Experimental Station, University of Illinois, IL, USA.

Garnsworthy, P.C., 1997. Fats in dairy cow diets. In Recent advances in animal nutrition (ed. P.C. Garnsworthy \& D.J.A. Cole), pp. 87-103. University of Nottingham, Nottingham, UK.

Goering, H.K. \& Van Soest, P.J., 1970. Forage fiber analysis (apparatus, reagents, procedures and some applications). In Agricultural handbook, no. 379. ARS-USDA, Washington, DC, USA.

Gorosito, A.R., Russell, J.B. \& Van Soest, P.J., 1985. Effect of carbon-4 and carbon-5 volatile fatty acids on digestion of plant cell wall in vitro. J. Dairy Sci. 68, 840-847.

Indexmundi, 2017. South Africa palm kernel meal imports by year. Retrieved 30 January 2017, from http://www.indexmundi.com/agriculture/?country=za\&commodity=palm-kernel-meal\&graph=imports.

Jenkins, T.C., 1993. Regulation of lipid metabolism in the rumen. J. Dairy Sci. 76, 3851-3863.

Kolver, E.S. \& De Veth, M.J., 2002. Prediction of ruminal pH from pasture-based diets. J. Dairy Sci. 85, $1255-1266$.

Kolver, E.S. \& Muller, L.D., 1998. Performance and nutrient intake of high producing Holstein cows consuming pasture or a total mixed ration. J. Dairy Sci. 81, 1403-1411.

Ministry of Agriculture, Fisheries and Food (MAFF), 1984. Energy allowances and feeding systems for ruminants. MAFF, HMSO, London, UK.

O'Mara, F.P., Mulligan, F.J., Cronin, E.J., Rath, M. \& Caffrey, P.J., 1999. The nutritive value of palm kernel meal measured in vivo and using rumen fluid and enzymatic techniques. Livestock Prod. Sci. 60, 305-316. 
Payne, R.W., 2014. Part 2: Statistics. In GenStat ${ }^{\circledR}$ for Windows ${ }^{\mathrm{TM}}, 17$ th edition (ed. R.W. Payne). Hemel Hempstead, Hertfordshire, UK.

Robertson, J.B. \& Van Soest, P.J., 1981. The detergent system of analysis and its application to human foods. In The analysis of dietary fibre in food, volume 3 (ed. W.P.T. James \& O. Theander), pp. 158-276. Marcel Dekker, New York, NY, USA.

Roseler, D.K., Ferguson, J.D., Sniffen, C.J. \& Herrema, J., 1993. Dietary protein degradability effects on plasma and milk urea nitrogen and milk nonprotein nitrogen in Holstein cows. J. Dairy Sci. 76: 525-534.

Satter, L.D. \& Slyter, L.L., 1974. Effect of ammonia concentration on rumen microbial protein production in vitro. Br. J. Nutr. 32, 199-208.

Schroeder, G.F., Gagliostro, G.A., Bargo, F., Delahoy, J.E. \& Muller, L.D., 2004. Effects of fat supplementation on milk production and composition by dairy cows on pasture: a review. Livest. Prod. Sci. 86, 1-18.

Seymour, W.M., Campbell, D.R. \& Johnson, Z.B., 2005. Relationship between rumen volatile fatty acid concentrations and milk production in dairy cows: a literature review. Anim. Feed Sci. Technol. 119, 155-169.

Snedecor, G.W. \& Cochran, W.G., 1980. Statistical methods (7th edition). Iowa State University Press, pp. 507.

Tilley, J.M. \& Terry, R.A., 1963. A two-stage technique for the in vitro digestion of forage crops. J. Br. Grassl. Soc. 18, 104-111.

Van Amburgh, M.E., Van Soest, P.J., Robertson, J.B. \& Knaus, W.F., 2003. Corn silage neutral detergent fiber: refining a mathematical approach for in vitro rates of digestion. Proceedings of the 66th annual Cornell Nutrition Conference for Feed Manufacturers, 2003, Ithaca, NY, USA, pp. 99-108.

Van der Colf, J., Botha, P.R., Meeske, R. \& Truter, W.F., 2015. Seasonal dry matter production, botanical composition and forage quality of kikuyu over-sown with annual or perennial ryegrass. Afr. J. Range Forage Sci. 32, 133-142.

Van Wyngaard, J.D.V., Meeske, R. \& Erasmus, L.J., 2015. Effect of palm kernel expeller as supplementation on production performance of Jersey cows grazing kikuyu-ryegrass pasture. Anim. Feed Sci. Technol. 199, 29-40.

Virah-Sawmy, M., 2014. From by-product to buy product: Building markets for sustainable palm kernel expeller (PKE). WWF-Australia, NSW, Australia.

Wan Zahari, M. \& Alimon, A.R., 2004. Use of palm kernel cake and oil palm by-products in compound feed. In: Palm oil developments 40, pp. 5-9. Malaysian Palm Oil Board, Kuala Lumpur, Malaysia.

Webb, E.C., 1994. Synthesis of long chain fatty acids in ruminants and their effects on meat quality. PhD thesis, University of Pretoria, Pretoria, South Africa.

Wildman, E.E., Jones, G.M., Wagner, P.E., Boman, R.L., Troutt, H.F. \& Lesch, T.N., 1982. A dairy cow body condition scoring system and its relationship to selected production characteristics. J. Dairy Sci. 65(3), 495-501.

Zebeli, Q., Dijkstra, J., Tafaj, M., Steingass, H., Ametaj, B.N. \& Drochner, W., 2008. Modeling the adequacy of dietary fiber in dairy cows based on the response of ruminal $\mathrm{pH}$ and milk fat production to composition of the diet. J.Dairy Sci. 91, 2046-2066. 